\title{
The Proposed Damages Directive: The Real Lessons from the United States
}

Robert H. Lande

University of Baltimore School of Law, rlande@ubalt.edu

Follow this and additional works at: http://scholarworks.law.ubalt.edu/all_fac

Part of the Antitrust and Trade Regulation Commons, and the International Law Commons

\section{Recommended Citation}

The Proposed Damages Directive: The Real Lessons from the United States, 3 CPI Antitrust Chron. 2 (March 2014)

This Article is brought to you for free and open access by the Faculty Scholarship at ScholarWorks@University of Baltimore School of Law. It has been accepted for inclusion in All Faculty Scholarship by an authorized administrator of ScholarWorks@University of Baltimore School of Law. For more information, please contact snolan@ubalt.edu. 


\section{CPI Antitrust Chronicle}

March 2014 (2)

The Proposed Damages

Directive: The Real Lessons

from the United States

\section{Robert H. Lande \\ University of Baltimore School of Law}




\title{
The Proposed Damages Directive: The Real Lessons from the United States
}

\author{
Robert H. Lande ${ }^{1}$
}

\section{INTRODUCTION}

Europeans should be doubly cautious when they study the U.S. experience with private antitrust enforcement. Nevertheless, there are ten specific lessons they can learn. None, however, is consistent with the conventional wisdom in the international competition community that U.S.-style private enforcement has been a disaster. ${ }^{2}$ Each should help Europe objectively consider the Commission's proposed Directive concerning private enforcement of Competition Law. ${ }^{3}$

\section{TWO IMPORTANT REASONS FOR CAUTION}

Europeans should not trust anyone from the United States who gives advice on the subject of private enforcement of competition law without carefully and skeptically considering the source. When someone says, "I'm from the U.S. and I'm here to help you," remember that everyone has a bias and an agenda. All of my assertions should be discounted accordingly ${ }^{4}$ and heavily in light of the following more general caution:

${ }^{1}$ Venable Professor of Law, University of Baltimore School of Law, and a Director of the American Antitrust Institute. I would like to thank Neil Averitt, John Connor, Joshua Davis, and Albert Foer for valuable comments, and Timothy Hart for excellent research assistance. A version of this article will appear in SHAPING PRIVATE ANTITRUST ENFORCEMENT IN EUROPE (Mel Marquis \& Giorgio Monti, eds. forthcoming).

${ }^{2}$ Although not saying he agreed with it, former FTC Chair William Kovacic succinctly summarized the conventional wisdom as follows: "private rights of actions U.S. style are poison." See FTC:WATCH No. 708, FTC WATCH 4 (Nov. 19, 2007), http://www.ftcwatch.com/series/708/ (quoting William E. Kovacic speaking at an American Bar Association panel on Exemptions and Immunities). For an extensive compilation of additional criticisms of U.S. private cases see Joshua P. Davis \& Robert H. Lande, Toward an Empirical and Theoretical Assessment of Private Antitrust Enforcement, 36 SEATTLE UNIV. L. REV 1269, 1269-70, available at http://papers.ssrn.com/sol3/papers.cfm?Abstract_id=2132981\&download=yes [hereafter "Toward Assessment"].

${ }^{3}$ When some critics suggest the proposed Directive will move Europe closer towards a U.S.-style of private antitrust enforcement, they speak in almost apocalyptic terms. Because an extremely negative view of U.S. private enforcement is the accepted wisdom in the international competition community, proponents of expanded private rights in Europe are forced to go to great lengths to demonstrate they are not proposing a U.S.-style system. In fact, critics of private enforcement tend to make two (largely inconsistent) claims: that it does too little-it fails to provide meaningful recovery to victims - and that it does too much-it forces defendants to settle even groundless claims. Neither assertion has empirical support. For an extended analysis of these issues see Joshua P. Davis \& Robert H. Lande, Defying Conventional Wisdom: The Case For Private Antitrust Enforcement, 48 GEORGIA L. REV. 1, 17 (2013), available at http://papers.ssrn.com/sol3/papers.cfm?Abstract_id=2217051 [hereafter "Defying Conventional Wisdom"].

${ }^{4}$ In the interest of full disclosure, my own background includes employment as an enforcer at the U.S. Federal Trade Commission, as a lawyer at Jones Day where I represented defendants more often than I represented plaintiffs, and as a professor. I also have worked as a consultant to law firms from time to time and am a co-founding Director of the American Antitrust Institute. 
Don't trust anyone giving advice about private enforcement policy unless his or her recommendations are based upon reliable empirical evidence. This especially includes the conventional wisdom that private antitrust enforcement in the United States has been a mistake Europe should avoid. A careful examination of the underpinnings of this criticism actually demonstrates that this consensus is not based upon reliable evidence. ${ }^{5}$ Rather, this conclusion derives only from opinions, anecdotes, and hypotheticals. ${ }^{6}$

It is essential, moreover, that you do not require proponents of private enforcement to persuade you beyond a reasonable doubt that the critics' opinions are wrong. Rather, a proper assessment should begin from a position of neutrality, and the proper analysis and resolution of the issues should involve neutrally weighing which side has presented better evidence supporting their assertions. ${ }^{7}$

\section{TEN SPECIFIC LESSONS FROM THE UNITED STATES}

There is a significant amount of empirical evidence concerning the U.S. experience with private enforcement that can be useful for Europeans considering expanding private rights of action. The following lessons are based upon evidence that, while not perfect, is the best that is available. None of these lessons are consistent with the conventional wisdom in the competition law field.

${ }^{5}$ See Defying Conventional Wisdom, supra note 3, at 3-8.

${ }^{6}$ As you scrutinize the conclusions of critics of U.S. private enforcement please do so with skepticism because:

1. Critics' hypotheticals or anecdotes do not count as reliable empirical evidence. Almost everything involving private enforcement-good and bad-has happened on occasion. The crucial issue for policy purposes is how often or how frequently they occur. When a critic asserts that something has happened a couple of times this is not proof that it is a typical or common outcome. It may well be anomalous.

2. An anecdote should count even less when it involves the person alleging it because these anecdotes might be self-serving. Often, a defense lawyer will recount a private litigation horror story without any opportunity being given for a response from other side. Please insist on listening to all sides before you reach a judgment.

3. A lawyer giving advice based upon their 30 years of experience, especially 30 years mostly spent doing defense work, is not presenting neutral evidence. We're all advocates and effective advocates first convince themselves that their positions are correct. Although every one of us believes we're neutral, it's very difficult to be neutral after you've spent most of a 30-year career representing one side of a controversy.

4. The older the evidence, the more it should be discounted. Private enforcement in the United States today is very different from the cases that were brought a generation or two ago. Many of the older private cases were substantively weak or resulted in questionable relief. Further, some longstanding critics of U.S. private enforcement formed their initial views when they were young, and it can be difficult for anyone to change their first impression, despite the changes in the field that have arisen during the last 30 years.

${ }^{7}$ Beware of critics giving advice that explicitly or implicitly places the burden of persuasion on the other side. In the foggy world of competition policy, whichever side has the burden of proof will be at a significant disadvantage. Some critics of U.S. private enforcement say in effect, "Here's what I believe, and although I don't have any empirical evidence for my positions you can trust me because it's based upon my 30 years of experience. Make the other side prove beyond a reasonable doubt that my assertions are false." This is especially unfair if the critics offer only hypotheticals or self-serving anecdotes to support their views. 


\section{A. Private Enforcement Has Provided Substantial Compensation to U.S. Victims of Anticompetitive Activity}

This fundamental point often gets lost during the heated and wide-ranging debates. It is so significant that it warrants being placed as the first substantive lesson for the European Union.

Professor Joshua Davis and I recently studied 60 large and relatively recent private U.S. antitrust cases. ${ }^{8}$ These cases returned a total of $\$ 33.8-\$ 35.8$ billion in cash to victims of anticompetitive behavior. ${ }^{9}$ These figures do not include products, discounts, coupons, or the value of injunctive relief or precedent-only cash. Consequently, these totals significantly understate the actual benefits to the victims. ${ }^{10}$ And, of course, we studied only 60 cases (albeit 60 of the largest private U.S. cases) out of the many hundreds of private cases filed in the United States in recent years.

The proposed Directive has as its primary goal to compensate European victims of anticompetitive behavior. ${ }^{11}$ The U.S. experience shows that private enforcement has the potential to do this. Moreover, there is no other practical way to achieve this goal.

\section{B. The Assertion that Remedies Secured by Private Cases Usually are Valueless is Contradicted by the Empirical Evidence}

Critics of U.S. private antitrust actions frequently assert that the remedies typically secured by U.S. private actions are at best dubious and often are completely worthless. Their contention is that the most common remedies consist solely of worthless coupons, meaningless discounts, and obsolete products, or cash recoveries that were subsequently consumed by private attorney fees and claims administration expenses. According to many critics, the only ones to benefit from private enforcement are attorneys. ${ }^{12}$

None of the critics who make these charges, however, offer evidence beyond opinions, hypotheticals, and occasional anecdotes. ${ }^{13}$ Indeed, for the 60 cases Professor Davis and I recently studied, our best estimate (based on empirical evidence) is that, overall, only 20 percent of the

${ }^{8}$ For an analysis of these 60 cases see Defying Conventional Wisdom, supra note 3.

${ }^{9} \mathrm{Id}$. at 17.

${ }^{10} \mathrm{Id}$. at 16. For a large number of methodological issues and caveats associated with this study see Id. and Robert H. Lande \& Joshua P. Davis, Benefits From Private Antitrust Enforcement: An Analysis of Forty Cases, 42 U. SAN FRANCISCO L. REV 879, 889-91, available at http://papers.ssrn.com/sol3/papers.cfm?Abstract_id=1090661 [hereafter "Benefits"]. As an example of the complications involved, we counted multiple cases involving the same or closely related cartels as a single case. Thus, even though a huge number of private cases were filed against the international vitamins cartel (and this "cartel," moreover, easily could be considered to be multiple cartels) we counted all these cases as one.

${ }^{11}$ See Commission Proposal for a Directive of the European Parliament and of the Council on certain rules governing actions for damages under National Law for infringements of the Competition Law Provisions of the European Union, at 30-31, COM (2013) 404 (Oct. 6, 2013).

${ }^{12}$ Of course, the private lawyers deserve compensation. This is especially true because plaintiff attorneys bear the risk of no recovery, cost of lost time, and usually discovery expenses as well.

${ }^{13}$ For example, Professor Daniel Crane asserted that "issuing [class members] a check is often so expensive that administrative costs swallow the entire recovery.” Daniel Crane, Optimizing Private Enforcement, 63 VANDERBILT L. REv. 675, 683 (2010). To support his statement, Professor Crane cited a 41 year-old article by Judge Posner that made a similar claim but contained no empirical support. See Toward Assessment, supra note 2, at 1305 (discussing the lack of foundation for Professor Crane's assertion). 
recoveries went for attorney fees and claims administration expenses. ${ }^{14}$ The rest was returned to the victims.

Nor have the critics who claim that private U.S. antitrust cases typically have returned only worthless coupons, meaningless discounts, or obsolete products to victims ever supported their conclusions with systematic evidence. They give opinions, make assertions, and provide anecdotes and hypotheticals. They also sometimes examine what happened in other areas of law and simply assert that these outcomes also occur as a consequence of contemporary U.S. private antitrust cases. ${ }^{15}$ But they never offer systematic evidence from antitrust cases to support their opinions. (Interestingly, only one of the cases Professor Davis and I examined involved a coupon remedy-the Auction Houses cases. However, those coupons were fully redeemable for cash if they were not used for 5 years and, again, we did not take the coupons into account in assessing the benefits of the litigation; we considered only the cash recovery. $)^{16}$

Abuses naturally occur from time to time in private antitrust cases, as they do almost everywhere in the legal system. However, a majority of the most egregious examples are from other areas of law or are quite old. No one has ever presented reliable evidence showing that examples are common today or typical of contemporary private antitrust cases brought in the United States.

\section{Most Successful U.S. Cases are Likely to Have Involved Anticompetitive Conduct}

Almost every U.S. private case that results in a remedy does so through a settlement, ${ }^{17}$ so their underlying merits have not been definitively reviewed by a judge. Critics often use the fact that most of these cases settled to assert that they were meritless. They sometimes claim that U.S. plaintiffs often receive huge sums from meritless cases and that private antitrust actions often amount to blackmail or extortion. ${ }^{18}$

Since almost anything can happen, there is no doubt that some U.S. settlements did not involve anticompetitive conduct, and because almost all of the cases Professor Davis and I studied settled, one reasonably might ask whether they involved anticompetitive conduct. Of course, opinions about specific cases will vary, and very few conclusions can fairly be made about the merits of settlements.

Nevertheless, there are good reasons to think the cases we studied involved legitimate claims. The same underlying conduct supporting the settlements gave rise to criminal penalties in 17 of the 60 cases; to civil relief by the government in 17 cases; to a trial that defendants lost in 15 cases; and to plaintiffs surviving or prevailing at summary judgment or judgment as a matter of law in 14 cases. ${ }^{19}$ Overall, 88 percent of the cases exhibited at least one form of validation as to

${ }^{14}$ See Defying Conventional Wisdom, supra note 3, at 46-48.

${ }^{15} \mathrm{Id}$. For a summary of additional criticisms of private antitrust enforcement, see Benefits, supra note 10, at 884-89.

${ }^{16} \mathrm{Id}$. at $901 \mathrm{n}$. 81 . To be conservative, however, we did not count these coupons in our cash totals.

${ }^{17}$ See, for example, Toward Assessment, supra note 2, passim.

${ }^{18}$ See Benefits, supra note 10 , at 884-88.

${ }^{19}$ Some cases have more than one indicia of merit. See Defying Conventional Wisdom, supra note 3, at 18-19. 
their merits. ${ }^{20}$ (Only 7 of 60 cases did not have at least one of these indicia of validation; these 7 cases settled too early for a substantive evaluation of their merits).$^{21}$

Although this does not prove that these cases involved anticompetitive conduct, to be fair one should compare these indicia of validity to the evidence underlying critics' charges that these and other cases constituted meritless, legalized blackmail. What evidence do critics provide to back up their assertions? Essentially...they offer nothing. Only anecdotes, hypotheticals, and opinions-no studies, statistics, or reliable evidence. There is no indication that any of the cases Professor Davis and I studied lacked merit, except of course for the self-serving assertions of the defendants involved. It is ironic that the conventional wisdom about the lack of merit of U.S. private antitrust enforcement itself lacks merit.

\section{Most Large U.S. Private Recoveries are Opt-Out Class Action Contingent Fee Cases}

Of the 60 large private U.S. cases Professor Davis and I studied, 47 were opt-out ${ }^{22}$ class action suits brought by attorneys who were working for a contingency fee. ${ }^{23}$ These cases recovered approximately two-thirds of the $\$ 33.8-\$ 35.8$ billion recovered by private antitrust plaintiffs in our study. ${ }^{24}$

Even though some European nations allow opt-out class action cases, ${ }^{25}$ the European Union only permits opt-in class action cases, ${ }^{26}$ and these cases typically recover damages for only a tiny percentage of victims. ${ }^{27}$ Nor does the European Union allow lawyers to receive contingency fees, ${ }^{28}$ and this limitation severely restricts the ability of most consumer-plaintiffs to recover. Although some business victims will be able to sue successfully if the proposed Directive is enacted, the vast majority of consumer-victims and small business-victims will continue to be uncompensated.

The 60 cases Professor Davis and I studied were among the largest private actions ever brought in the United States and therefore might not be representative of either U.S. private cases as a whole or the majority of cases likely to be filed in Europe under the proposed Directive. Nevertheless, the European lack of opt-out class action cases and contingent fee arrangements suggests that even if the proposed Directive is enacted, most European victims of anticompetitive behavior will remain uncompensated.

${ }^{20} I d$.

${ }^{21} I d$.

22 "Opt-out" cases can include every class member unless they decide not to participate in the class.

${ }^{23}$ See Toward Assessment, supra note 2, at 1286-87.

${ }^{24} \mathrm{Id}$. at 1287.

${ }^{25}$ See Albert A. Foer \& Jonathan W. Cuneo, The International Handbook of Private EnForcement of Competition LAW 277-414 (Albert A. Foer \& Jonathan W. Cuneo, eds. 2010).

${ }^{26}$ See proposed Directive at Commission Recommendation of 11 June 2013 on common principles for injunctive and compensatory collective redress mechanisms in the Member States concerning violations of rights granted under Union Law 2013 O.J. (L 201) 60, 64 (EU).

${ }^{27}$ See Albert A. Foer \& Jonathan W. Cuneo, supra note 24, at 296-315.

${ }^{28} I d$. 


\section{E. Indirect Purchasers Usually Recover Much Less than Direct Purchasers}

In the United States, there were almost always extra proof problems and other complications involving indirect purchaser cases. ${ }^{29}$ These issues have tended to make indirect purchaser recoveries much smaller than those in direct purchaser cases. ${ }^{30}$ For example, of the 60 large cases Professor Davis and I studied, only 11 involved indirect purchasers, and the indirect purchasers recovered only $\$ 2.2$ billion, compared to the recovery of $\$ 13.1-\$ 14.6$ billion by direct purchasers in those 44 cases. ${ }^{31}$

Apparently, in Europe there are unclear standards involving such direct/indirect purchaser issues as the pass-on defense..$^{32}$ Nevertheless, if the U.S. experience is a guide, the relatively modest payments that will be made to indirect victims won't cause the sum of payments to direct and indirect purchasers to exceed 100 percent of the overcharges.

\section{F. Victims in the United States Rarely Were Overcompensated}

Even though U.S. law theoretically awards "treble damages," U.S. victims rarely have been overcompensated. Taking the actual U.S. experience into account, there is no reason to expect that overcompensation will be a problem in Europe.

This, of course, means that defendants rarely will pay more than the inflated profits they obtained through anticompetitive conduct. ${ }^{33}$ This is so, despite the possibility victims will receive seemingly "duplicative" recoveries under the laws of E.U. Member States in addition to facing liability to both direct and indirect purchasers.

The U.S. antitrust laws theoretically award "treble damages" plus attorney fees to successful plaintiffs. ${ }^{34}$ However, almost every successful U.S. case settles, and the median settlement was less than 50 percent of single damages. ${ }^{35}$ Thus, even though the $\$ 33.8-\$ 35.8$

${ }^{29}$ See Robert H. Lande, New Options for State Indirect Purchaser Legislation: Protecting the Real Victims of Antitrust Violations, 61 AlABAMA L. REV. 447, 456 (2010), available at

http://papers.ssrn.com/sol3/papers.cfm?abstract_id=1267202.

${ }^{30}$ In addition, many states do not allow indirect purchaser suits.

${ }^{31}$ See Towards Assessment, supra note 2, at 1286.

${ }^{32}$ See proposed Directive, supra note 11, at 17-18.

${ }^{33}$ However, under the standard optimal deterrence model, defendants should pay more than their illegal gains because the probability that their activity will be discovered and sanctioned is less than 100 percent. See John M. Connor \& Robert H. Lande, Cartels as Rational Business Strategy: Crime Pays, 34 CARdOZO L. REV. 427, 431-35 (2012), available at http://papers.ssrn.com/sol3/papers.cfm?Abstract_id=1917657\&download=yes [hereinafter "Cartels as a Business Strategy"].

${ }^{34}$ See 15 U.S.C. Section 15(a)(i) (2000).

${ }^{35}$ Defendants should not be expected to settle for their maximum possible exposure. Indeed, for a variety of complex reasons even settlements as high as single damages are unusual. Professor John Connor and I are studying a group of 66 cartel cases where a neutral scholar calculated the cartel's overcharges in the U.S. market. We compared these results to the damages secured in private antitrust cases filed against these cartels in the United States. Despite the entitlement to treble damages, our tentative findings are that the victims of only 14 cartels received more than $100 \%$ of their damages. The rest- 52 cases-yielded less than actual damages. In fact, half settled for less than 50 percent of actual damages and the median of the settlements was only 45 percent of single damages. These figures are preliminary and are subject to a large number of caveats. They also omit consideration of the value of products, coupons, and discounts. For these reasons the actual median settlement could be greater-perhaps as high as 75 percent of single damages. 
billion Professor Davis and I calculated as being returned to victims in recent U.S. cases is a lot of money, it probably was not nearly enough to fully compensate all the victims in these cases. ${ }^{36}$

By contrast, the proposed Directive provides for single damages, defined to include prejudgment interest and lost profit. ${ }^{37}$ Pre-judgment interest and lost profit are not features found in U.S. antitrust, and they often can be quite significant. Nevertheless, as noted above, the U.S. "treble damages" remedy usually yields settlements of less than 50 percent of actual damages. If this ratio were to apply to European private cases under the proposed Directive, European victims would be expected to recover on average significantly less than 50 percent of actual damages. Even in the cases where some victims additionally recover under the laws of individual European nations, their total compensation is likely to be far less than the actual harm they suffered.

Moreover, if the proposed Directive is enacted, there are at least two additional important reasons why most victims will continue to be uncompensated. First, recall that most large private U.S. antitrust recoveries are opt-out class action cases. By contrast, the proposed Directive allows only opt-in class action cases, which typically recover far less. Second, most private U.S. recoveries come in contingent fee cases. These are rarely if ever permitted in Europe, even though without them, consumers and small businesses seldom will be able to bring competition cases.

For the above reasons, the proposed Directive is unlikely to come close to achieving its goal of fully compensating European victims of anticompetitive behavior, and European victims will rarely be overcompensated.

\section{G. The U.S. Private Cases Have Helped Deter Anticompetitive Conduct Significantly}

The purpose of the proposed Directive is, of course, to compensate victims of anticompetitive behavior. ${ }^{38}$ Cases arising under the Directive also will help deter anticompetitive conduct, and this should be considered a welcomed side-benefit.

Deterrence of anticompetitive behavior is often believed to be the concern only of government enforcement. Nevertheless, a study I performed with Professor Davis shows that private enforcement in the United States likely deters a substantial amount of anticompetitive activity. In fact, it probably deters more anticompetitive behavior than even the highly acclaimed anti-cartel program of the U.S. Department of Justice. ${ }^{39}$ This is true even though the Antitrust Division's cases often result in prison sentences for cartel participants! ${ }^{40} \mathrm{We}$ hope that this

${ }^{36}$ This is especially likely to be true because roughly 20 percent of the U.S. recoveries were consumed by the victims' attorneys' fees and claims administration expenses. See Defying Conventional Wisdom, supra note 3, at 4647.

${ }^{37}$ See proposed Directive, supra note 11, at 2.

${ }^{38}$ See id. at 4.

${ }^{39}$ Robert H. Lande \& Joshua P. Davis, Comparative Deterrence From Private Enforcement and Criminal Enforcement of the U.S. Antitrust Laws, 2011 BRIGHAM YOUNG UNIV. L. REV. 315, 317 (2011), available at http://papers.ssrn.com/sol3/papers.cfm?Abstract_id=1565693.

${ }^{40} \mathrm{We}$ use $\$ 6$ million as having approximately the equivalent deterrent effect of a year in prison. Id. 
finding will cause many in both the United States and in Europe to reevaluate their views as to the overall efficacy of private antitrust enforcement.

Of course, recent fines for violations of competition law have been much higher in Europe than in the United States. In 2013 the total U.S. antitrust fines were $\$ 1.88$ billion, ${ }^{41}$ while for the European Union they were $\$ 2.50$ billion. ${ }^{42}$ Similarly, for the last five years the United States and European Union total fines were, respectively, $\$ 4.19$ billion $^{43}$ and $\$ 11.92$ billion $^{44}$ and for the last ten years the totals were, respectively, $\$ 6.74$ billion $^{45}$ and $\$ 23.21$ billion. ${ }^{46}$ As impressive as these European totals have been, however, they are smaller than the recoveries in just the 60 private U.S. cases that Professor Davis and I studied. Surely in Europe-like in the United States-private actions have the potential to significantly deter anticompetitive conduct.

The proposed Directive's private actions are not likely to have such dramatic deterrence effects for the reasons given in Section F, supra. Nevertheless, the Directive's deterrence effects have the potential to be important. These should be considered a welcomed side-benefit of the Directive, especially because these cases will cost European governments and taxpayers very little in enforcement costs.

\section{H. Despite the Combination of U.S. Private Actions and Government Enforcement, There Has Been No Evidence of Over-deterrence}

If the proposed Directive is enacted, firms might well pay both a fine to the European Union and damages in private cases. The U.S. experience strongly suggests, however, that this combination will not result in over-deterrence.

A recent study I co-authored with Professor John Connor analyzed the optimal deterrence issue in the cartel context. We analyzed whether existing U.S. cartel sanctions are optimal in achieving deterrence. ${ }^{47}$

The United States imposes a diverse array of sanctions against collusion: criminal fines and restitution payments for firms in addition to prison, house arrest, and fines for corporate officials. Both direct and indirect victims can sue for mandatory treble damages and attorney's

${ }^{41}$ See Melissa Lipman, EU eclipses DOJ with 2.5B in antitrust fines in 2013, Law360.com (January 8, 2014 7:02PM), http://www.law360.com/articles/499516/eu-eclipses-doj-with-2-5b-in-antitrust-fines-in-2013.

${ }^{42} \mathrm{Id}$. at 1 .

${ }^{43}$ See Toward Assessment, supra note 2, at 1329-30, app. Tbl. 13,14 (2013), (for years 2003-2011); Department of Justice, Antitrust Division, Division Update Spring 2013, (last visited January 10, 2013), http://www.justice.gov/atr/public/division-update/2013/criminal-program.html (for year 2012); Lipman, supra note 40 , at 1 (for year 2013).

${ }^{44}$ See id. (for year 2013); European Commission, Competition: Cartel statistics, 1 (Dec. 2013), http://ec.europa.eu/competition/cartels/statistics/statistics.pdf.l (for year 2012); Slaughter \& May, The EU Competition Rules on Cartels, app. 1 at 26 (May 2012), available at

http://files.teneoevents.eu/media/emailings/pdf/the-eu-competition-rules-on-cartels.pdf (for years 2003-2011).

${ }^{45}$ See Toward Assessment, supra note 2, at 1329-30, app. Tbl. 13,14 (2013), (for years 2003-2011); Department of Justice, supra note 42 (for year 2012); Lipman, supra note 40, at 1 (for year 2013).

${ }^{46}$ See Lipman, supra note 40, at 1 (for year 2013); European Commission, supra note 43 (for year 2009-2012); Slaughter \& May, supra note 43, at 26 (for years 2003-2009).

${ }^{47}$ See Cartels as a Business Strategy, supra note 32. 
fees. ${ }^{48}$ The multiplicity of sanctions has helped give rise to the strongly held-but until recently never seriously examined-conventional wisdom in the antitrust field that these sanctions are not just adequate, but they are likely excessive.

We analyzed the issue using the standard optimal deterrence approach. ${ }^{49}$ The model is predicated upon the belief that corporations and/or individuals contemplating illegal collusion will be deterred only if expected rewards are less than expected costs, adjusted by the probability the illegal activity will be detected and sanctioned. To undertake this analysis, we first calculated the expected rewards from cartelization using a new and unique database containing information concerning 75 cartel cases.$^{50} \mathrm{We}$ surveyed the literature to ascertain the probability that cartels are detected and that detected cartels are sanctioned. We calculated the size of the sanctions involved for each case in our sample. These included corporate fines, individual fines, payouts in private damage actions, and the equivalent value (or disvalue) of imprisonment or house arrest for the individuals convicted. ${ }^{51}$

Our analysis showed that, overall, the combined U.S. cartel sanctions are only 9-21 percent as large as they should be to protect potential victims of cartelization optimally. This means that despite the existing sanctions, collusion remains a rational business strategy. Cartelization is a crime that, on average, pays. In fact, it pays very well. There is currently no cartel over-deterrence in the United States. Nor is the proposed Directive likely to cause overdeterrence in Europe.

\section{Many Private Cases Were Not Follow-ups to Government Litigation}

Not all of the private actions brought in the United States were follow-ups to government enforcement. The Davis/Lande study, for example, found that more than one-third of the 60 cases it studied were not follow-ups to government actions, and an additional 12 were significantly broader than the original government cases. $.^{52} \$ 8.4-\$ 10.2$ billion was recovered from the cases that did not follow U.S. federal, U.S. state, or E.U. government enforcement actions. In these cases, private plaintiffs uncovered the violations, initiated, and pursued the litigation with the government following the private plaintiffs' lead or playing no role at all. Another $\$ 11$ billion came from cases with a mixed private/public origin or from cases that were significantly broader than the government's original case..$^{53}$

${ }^{48}$ In theory victims also can sue for the allocative inefficiency effects of market power or the "umbrella" effects of market power. In the United States there has never been an award for the allocative inefficiency effects of market power, and awards for the "umbrella effects" of market power are rare or non-existent. Id. at 457-62. Don't expect too many of these awards in European cases.

${ }^{49} \mathrm{We}$ also incorporated a number of behavioral insights into our analysis, but they only changed our proposed remedies. $I d$., passim.

${ }^{50} I d$.

${ }^{51}$ For example, we use $\$ 6$ million as having approximately the equivalent deterrent effect of either a year in prison or a year of house arrest. $I d$.

${ }^{52}$ See Defying Conventional Wisdom, supra note 3, at 30. The private cases often were broader in terms of time or geography or included more defendants or alleged violations. They often involved more defendants than the government cases, more causes of action, and greater relief (in some instances the only relief).

${ }^{53} \mathrm{Id}$. 
It is doubtful, however, that the proposed Directive will result in nearly as many private cases that are not follow-ups to government enforcement. In fact, because the European Union has very different discovery procedures, ${ }^{54}$ and allows neither opt-out class action cases nor contingent fee cases, the number of private actions that do not follow government enforcement may be rare.

\section{J. U.S. Victims Received Billions of Dollars from Foreign Violators of U.S. Antitrust Law}

The final point might be called a "balance of payments" or a "fairness to Europeans" consideration. A study by Dr. Connor found that, since 1999, foreign violators of U.S. antitrust laws returned more than $\$ 13$ billion to U.S. victims of foreign cartels and monopolies. Indeed, in just the 60 cases Professor Davis and I studied, at least $\$ 6-\$ 8$ billion was recovered from non-U.S. companies, including more than $\$ 3$ billion in cases against members of the vitamins cartels. ${ }^{55}$ These totals do not include recoveries of products, discounts, coupons, or the value of injunctive relief or legal precedent.

For political and other purposes, it could be highly significant that a substantial portion of these recoveries came from foreign lawbreakers. Without private enforcement, these foreign actors could have preyed on participants in the U.S. economy while retaining almost all of their spoils.

As you know, many E.U. law violators are from the United States or Asia. A vigorous European private enforcement system surely would return a considerable number of Euros to European consumers and corporations from U.S. and other foreign actors.

\section{CONCLUSIONS}

The Commission's proposed Directive concerning the private enforcement of Competition Law certainly would be beneficial for victims of anticompetitive conduct because it would allow some of them to obtain some compensation. It does not, however, go nearly far enough. Primarily, because it does not allow opt-out class action cases or contingent fees, it will leave most victims uncompensated.

It is certainly possible the proposed Directive has flaws and will result in some unintended or undesirable consequences. But today, there is a much greater flaw in E.U. competition law. Because of its lack of effective private enforcement, most victims are uncompensated. The injustice from not compensating these victims is more important than any injustices that might happen to companies that violate E.U. law.

If the proposed Directive is enacted, it should be assessed after it has been in effect for 3 to 5 years. The U.S. experience suggests this examination will produce a number of important findings: (i) most of the private cases will be found to be meritorious; (ii) despite possible suits under Member State as well as E.U. law, and by both direct and indirect victims, most victims will still be uncompensated or undercompensated; (iii) deterrence of anticompetitive activity will

\footnotetext{
${ }^{54}$ For an extensive discussion on these issues see Albert A. Foer \& Jonathan W. Cuneo, supra note 24 (comparing and contrasting the United States and European approaches in detail).

${ }^{55}$ See Defying Conventional Wisdom, supra note 3, at 17.
} 
improve; and (iv) E.U. victims will recover a considerable number of Euros from non-E.U. violators. Further, the total amounts paid by violators in suits filed Europe-wide as a result of the new Directive, and also under the laws of individual European nations, by both direct and indirect purchasers, will rarely if ever exceed 100 percent of the actual damages.

After this retrospective is complete, the Commission should consider ways to further improve its private enforcement system. Perhaps at that time, the European Union will reconsider allowing opt-out class action cases or contingent fees. If the Commission does reevaluate these issues, it should, of course, do so only on the basis of objective, reliable empirical information, and not on the basis of rumor, unsupported conventional wisdom, opinions, hypotheticals, or anecdotes.

In the meantime, individual Member States are free to do more than the minimum, set out by the proposed Directive. This short article suggests only a few of the ways ${ }^{56}$ they could enact laws that are extremely likely to help victims of anticompetitive behavior.

${ }^{56}$ As another possibility, the proposed directive contains a presumption that cartels overcharge, but the presumption does not specify an overcharge amount. See proposed directive, supra note 11, at 39. Perhaps a revised directive should contain a presumption that cartels overcharge by 10 percent, the amount specified by the United States sentencing commission in its antitrust guidelines. A more realistic alternative would be to adopt a 20 percent presumption, which would still be less than the typical amount of cartel overcharges found in a study I performed together with Professor Connor. See John M. Connor \& Robert H. Lande, How High Do Cartels Raise Prices? Implications for Reform of the Antitrust Sentencing Guidelines, 80 TULANE LAW. R. 513 (2005), available at http://papers.ssrn.com/sol3/papers.cfm?abstract_id=787907.

This study identified about 200 serious social science studies of cartels, and these studies contained 674 observations of average overcharges. Our primary finding is that the median cartel overcharge for all types of cartels over all time periods has been 25 percent; 17-19 percent for domestic U.S. cartels, and 30-33 percent for international cartels. Thus, in general, international cartels have been about 75 percent more effective in raising prices than domestic cartels. Since the United States has had, historically, by far the toughest system of anticartel sanctions, this could imply that these sanctions have been having significant effects.

We also performed a survey of every final verdict we could find in decided U.S. collusion cases. Only 3 of the 25 cases we found were international cartels. This survey produced an average median overcharge of 21.6 percent and an average mean overcharge of 30.0 percent. Thus, the 25 U.S. cartel decisions produced average overcharges that were quite comparable to the results of the much larger set of economic estimates. Id. 